Jurnal Inovasi Pendidikan MH Thamrin | Volume 3 nomor 2, Oktober 2019

\title{
THE IMPROVING STUDENTS'WRITING SKILL THROUGH CLUSTERING TECHNIQUE
}

\author{
Megawati \\ STKIP Kusuma Negara \\ Megawati86@stkipkusumanegara.ac.id
}

\begin{abstract}
Students four grade semester English Education Department have difficult in writing. They have limitation in English vocabulary building, students didn't understand systematically in writing. They usual use common words in writing English so that they weak in writing skill. Lecturer choose clustering technique to improve students'writing skill. The advantages this technique can mapp students'mind, an idea or theme with symbols and diagram after that they can improve become written or text. Furthermore all of the content in which they want to write based on the outline. This research aim to know improving students'writing skill through clustering technique on students STKIP Kusuma Negara, Jakarta. It is qualitative research using classroom action research method. It was conducted two cycle. Each of cycle consist of four steps. There are planning, acting, observing and reflecting. This research was conducted with the subject twenty five students in fourth semester English Education STKIP Kusuma Negara Jakarta. Data were collected through interview, observation and test. The result of this research is improving students'writing skill through Clustering Technique showed an increasing percentage and average score. Cycle I was $32 \%$ students pass in writing skill or the average score is 73.28 , in Cycle II was $88 \%$ students pass in writing skill or the average score is 81.6 . The students given positive responses, they were enthusiastic and motivated when they written in English by Clustering Technique. Based on the result, it can be concluded Clustering Technique could improve the students'writing skill on STKIP Kusuma Negara.
\end{abstract}

Keywords: Students'writing skill, Clustering Technique, Classroom Action Research

\begin{abstract}
Abstrak
Mahasiswa semester empat Program Studi Pendidikan Bahasa Inggris memiliki kesulitan dalam menulis. Mereka memiliki keterbatasan dalam perbendaharaan kosakata, selain itu mereka tidak memahami aturan dalam menulis. Mahasiswa terbiasa menggunakan kata-kata yang mudah atau umum dalam menulis sehingga mereka lemah dalam pemahaman menulis bahasa Inggris. Dosen menerapkan teknik Clustering untuk memperbaiki kemampuan menulis bahasa Inggris. Kelebihan dalam teknik tersebut adalah mahasiswa dapat memetakan ide, fikiran atau tema dalam sebuah symbol dan diagram setelah itu mereka dapat menjadikannya sebagai teks yang utuh. Penelitian ini bertujuan untuk mengetahui peningkatan kemampuan menulis bahasa Inggris mahasiswa dengan teknik clustering di STKIP Kusuma Negara, Jakarta. Penelitian ini merupakan penelitian kualitatif dengan menggunakan metode Classroom Action Research. Penelitian yang dilakukan terdiri dari dua siklus. Setiap siklus terdiri dari empat tahapan. Tahapan tersebut adalah perencanaan, tindakan, observasi dan refleksi. Penelitian ini dilakukan
\end{abstract}


dengan mengambil sampel 25 mahasiswa semester IV Prodi Pendidikan Bahasa Inggris STKIP Kusuma Negara Jakarta. Data yang dikumpulkan berupa wawancara, observasi dan test. Hasil dari penelitian ini adalah terdapat peningkatan kemampuan menulis bahasa Inggris mahasiswa dengan teknik mind mapiing yang ditunjukkan dengan persentase ketuntasan serta nilai rata-rata. Pada siklus I terdapat $32 \%$ mahasiswa tuntas atau nilai rata-rata 73.28, pada siklus II terdapat 88 $\%$ atau nilai rata-rata 81.6. Mahasiswa memberikan respon yang baik selama proses pembelajaran, mereka antusias dan bersemangat ketika menulis bahasa Inggris dengan teknik Clustering. Berdasarkan hasil penelitian maka dapat disimpulkan bahwa teknik Clustering dapat meningkatkan kemampuan menulis bahasa Inggris mahasiswa di STKIP Kusuma Negara.

Kata Kunci: kemampuan menulis, teknik Clustering, Penelitian Tindakan Kelas

\section{INTRODUCTION}

Language always changes every time. Human uses language as the tool for share information, knowledge to another. Language formed as the habitual person in one location or area then they make agreement to use it as the communicate, so that people in one area have identity language for example sundanese, bataknese and others. In communication, we need understanding each other. Understanding between speaker and listener. Now development language increase with the high of the technology. The technology applies English because English is one of the International language in which people have to it for mastery. Laptop, mobile phone and electronics tools use English in using it. Furthermore develop advance of technology, It hopes that human can mastery English well. If the human can mastery English skill well, they can easy to follow developing globalization. For getting English well, we have to mastery all of those skill in English. There are speaking, writing, listening, and reading. Four those basic skills can getting by all the way, such as training, courses, high education or usual speaking in English every day. Speaking and writing are skills which in getting for productive English language skill. Meanwhile reading and listening are skill which we receive those skill from the expert in English for example native speaker, trainer, lecturer and so on. In high education writing as the one of basic skill in English lesson especially English Department. Writing is one of the activity in which write the idea or mind in a paper. Content of the written can be seen in one idea from the author. Writing in English is one of the competence in high education. For getting a good written, It needed a good skill in English. Students have got difficult in writing. Because they don't understand systematically in written. Each of the students have different mastery skill in English, this happens influenced by habitual in daily life. They usual use Indonesia so that they have limitation on vocabulary building. Limitation vocabulary English can cause students difficult in writing. Also students don't usual write in English. Students usually use vocabulary which they understand with the words, and also they didn't want to explore find new vocabulary. Moreover experiences which students get and lack ness motivation in writing. Many ideas which students write, it makes they didn't focus in order that idea in written in the outside from the planning. Lecturer have to determine what are technique, model or strategy in which appropriate with the students in high education. Because characteristic students in high education are different in school also it was determine successful level in writing skill. The lecturer choose clustering technique to improve students' writing skill. According to Dian (2018:131) Writing skill is a language skill that is used for indirect communication. The students can communicate their ideals and thought to others through a written form such as letter, message, or invitation for 
communication. It means that through writing, we can communicate by written with paper as the media, for example letter, send message by mobile phone or send e-email. According to Heaton (135:1988) Writing skills are complex and sometime difficult to teach, requiring mastery not only of grammatical and rhetorical device but also of conceptual and judgmental elements. It means that writing is the complex activity in teaching, when it transfers to other people we have to mastery the element of teaching writing such as vocabulary, language use, mechanics and others related with writing. According to Reid (1993: 102) The writing levels are broken into three more general levels; beginning, intermediate, and advanced. All levels are encouraged to use prewriting techniques (such as brainstorming, clustering, outlining, pre discussion of topic, pre reading, analysis of models), to determine audience and purpose in writing, to revise and to incorporate the use of dialogue journals. According To Widyawati (2018:136) in having good writing, the students have to know some of the rules in writing. They are such as using correct vocabulary, grammar, and spelling. It means to mastery writing skill we have to understanding structure and grammar, spelling, punctuation so that the written easy to understand by the people. According to Wiguna (2019: 33) the competency in writing effectively enables people from different culture and background to communicate. To make an understandable writing, the writers should master the way to write a good composition. It means that the students should be able to write a theme or motion based on the element in writing so the written can be understand by the reader. They can know what are the content and information of the text.

Clustering technique is formed diagram supporting details in which relation with the theme, an idea or motion. Clustering is a type of prewriting that allows you to explore many ideas as soon as they occur to you. According to Langan (2008:30) states that Clustering also known as diagramming or mapping, is another strategy that can be used to generate material for an essay. According to Rabadia in Cooper and Axelrod (1985:461) Clustering is an invention activity which reveals possible relations among facts and ideas. According to Rabadia in Braine and may (1996:21) Clustering is another effective method you could use to narrow a subject. It means that in clustering you can write a word in the middle diagram and then write narrow as a branch of the main word also components the others which has related with the central words. Pharr and Buscemi (1996:21) support that Clustering is the method see the developing essay by write the topic in the center of a paper then write the ideas around it by connecting with lines.

There are steps to making a Clustering Technique, students draw a diagram, box and circle in the middle and then make a line or narrow as the branch of the center. After that it describe with the branch and also supporting the main idea. Supporting idea explain when it occurs, where is happen, how is the way happen, whose the act, why it happens, and explain the characteristic of the place or things. Those steps are supported by Lunsford (2010:57):

1. Write down your topic in the middle of a blank piece of paper, and circle it.

2. In a ring around the topic circle, write what you see as the main parts of the topic. Circle each part, and draw a line from it to the topic

3. Think of more ideas, example, facts, or other details relating to each main part. Write each of these near the appropriate part, circle each one, and draw a line from it to the part

4. Repeat this process with each new circle until you can't think of any more details. Some trails may lead to dead ends, but you will still; have many useful connections among ideas According to Langan (2005:27), the applications of clustering technique are:

Begin by starting your subject in a few words in the center of a black sheet of paper. Then, as ideas and details come to you, put them in boxes or circles around the subject and draw lines to connect them to each other and to the subject. 
There are steps to making clustering, students write a theme which chosen in the center as keywords. After that it describe with the branch and also supporting the main idea. Supporting idea explain when it occurs, where is happen, how is the way happen, whose the act why it happens, and explain the characteristic of the place or things. Students add sub topic around the main idea in the center. Through clustering technique, students write concept before they write in English. In order that result of the written can be focus and also suitable with the draft. The written use handwriting and apply structure and grammar.

According to Tribble (1996:37-39) in Harmer (2007:326) the writing process is more complex than this, of course, and the various stages of drafting, reviewing, re-drafting and writing, etc, are done in a recursive, way: we loop backwards and move forwards between these various stages.

According to White and Arndt in Harmer (2007: 326) stress that writing is re-writing ... revision- seeing with new eyes-has a central role to play in the act of creating text.

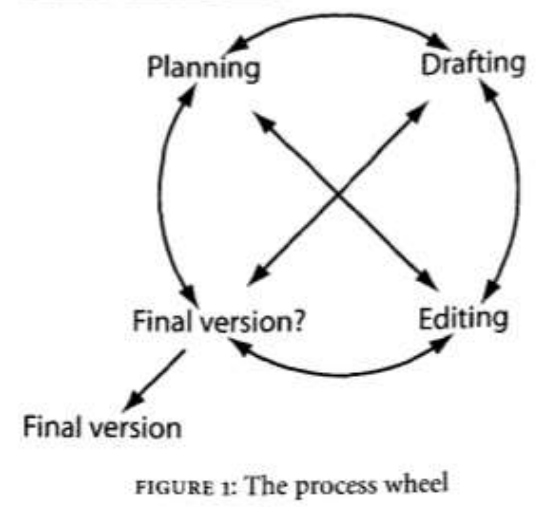

White and Arndt's (1991:5) It model can be represented diagrammatically, one of disadvantages of getting students to concentrate on the process of writing is that it takes time: time to brainstorm ideas or collect them in some other way; time to draft a piece of writing and then, with the teacher's help perhaps, review it and edit it in various ways before, perhaps, changing the focus, generating more ideas, redrafting, re-editing and soon. This cannot be done in fifteen minutes.

Procedure in writing means that students make discuss with the lecturer about making draft writing. Before students decide what draft which they write, lecturer give explanation and guidance about what the idea which they arrange. After that students appropriate structure and grammar with the idea which they write. Then students give review that relation with the idea as long as technique in writing, focus with the objective of writing. Lecturer give evaluation on the writings' idea also suggest which consideration in writing. Problem often appear in writing are limitation time learning writing in the classroom. Students more enthusiasm in writing English one time without continue writing, they need inspiration when they want to write. They didn't have an idea, when they ask to writing and it makes them difficult in writing. Moreover they assume that writing in English can finish as soon as possible as if play game.

Criteria of writing score based on Heaton (1998: 146)

\begin{tabular}{|l|l|l|}
\hline & SCORE & CRITERIA \\
\hline Content & $30-27$ & $\begin{array}{l}\text { Excellent to very Good : } \\
\text { Fluent expression ideas clearly stated/supported Succinct well } \\
\text { organized logical sequencing cohesive } \\
\text { Good to Average : }\end{array}$ \\
\hline
\end{tabular}




\begin{tabular}{|c|c|c|}
\hline & $21-17$ & $\begin{array}{l}\text { Sure knowledge of subject, adequate range, limited development of } \\
\text { thesis, mostly relevant to topic but lacks detail. } \\
\text { Fair to Poor: } \\
\text { Limited knowledge of subject, little substance, inadequate } \\
\text { development of topic. } \\
\text { Very Poor: } \\
\text { Does not show knowledge of subject, non-substantive, not pertinent, } \\
\text { not enough to evaluate. }\end{array}$ \\
\hline Organization & $13-10$ & $\begin{array}{l}\text { Excellent to very Good: } \\
\text { Fluent expression, ideas clearly stated/supported, succinct, well- } \\
\text { organized, logical sequencing, cohesive. } \\
\text { Good to Average : } \\
\text { Somewhat choppy, loosely organized but main ideas stand out, } \\
\text { limited support, logical but incomplete sequencing. } \\
\text { Fair to Poor: } \\
\text { Non-fluent, ideas confused, or disconnected, lacks logical } \\
\text { sequencing and development. } \\
\text { Very Poor: } \\
\text { Does not communicate, no organization, or not enough to evaluate. }\end{array}$ \\
\hline Vocabulary & $17-14$ & $\begin{array}{l}\text { Excellent to Very Good : } \\
\text { Sophisticated range, effective word/idiom choice and usage, word } \\
\text { form mastery, appropriate register. } \\
\text { Good to Average : } \\
\text { Adequate range, occasional errors of word/idiom form choice, usage } \\
\text { but meaning not obscured. } \\
\text { Fair to Poor: } \\
\text { Limited range, frequent errors of word/idiom form, choice, usage, } \\
\text { meaning confused or obscured. } \\
\text { Very Poor: } \\
\text { Essentially translation, little knowledge of English vocabulary, } \\
\text { idioms, word form, not enough to evaluate. }\end{array}$ \\
\hline $\begin{array}{l}\text { Language } \\
\text { use }\end{array}$ & $17-11$ & $\begin{array}{l}\text { Excellent to very Good: } \\
\text { Effective complex construction, few errors of agreement, tense, } \\
\text { number, word order/function, articles, pronoun, prepositions. } \\
\text { Good to Average : } \\
\text { Effective but simple construction, minor problems in complex } \\
\text { construction, several errors of agreement, tense, number, word } \\
\text { order/function, articles, pronoun, preposition but meaning seldom } \\
\text { obscured. } \\
\text { Fair to Poor : } \\
\text { Major problems in simple/complex construction, frequent errors of } \\
\text { negation, agreement, tenses, number, word order/function, articles, } \\
\text { pronoun, prepositions and/or fragments, run-ons, deletions, meaning } \\
\text { confused or obscured. } \\
\text { Very Poor: } \\
\text { Virtually no mastery of sentence construction rules, dominated by }\end{array}$ \\
\hline
\end{tabular}




\begin{tabular}{|l|l|l|}
\hline & & errors, does not communicate, or not enough to evaluate. \\
\hline Mechanics & 5 & $\begin{array}{l}\text { Excellent to Very Good : } \\
\text { Demonstrated mastery of conventions, few errors of spelling, } \\
\text { punctuation, capitalization, paragraphing. } \\
\text { Good to Average : } \\
\text { Occasional errors of spelling, punctuation, capitalization, } \\
\text { paragraphing but meaning not obscured. } \\
\text { Fair to Poor : } \\
\text { Frequent errors of spelling, punctuation, capitalization, paragraphing, } \\
\text { poor handwriting, meaning confused or obscured. } \\
\text { Very Poor : } \\
\text { No mastery of conventions dominated by errors of spelling, } \\
\text { punctuation, capitalization, paragraphing, handwriting illegible, not } \\
\text { enough to evaluate. }\end{array}$ \\
\hline Total Score & 2 & $\frac{\text { C+V+O+LU+M }=}{5}$ \\
\hline
\end{tabular}

For getting average score, wring skill in English based on Reid standard in Riswanto (2012:65) Writing category

\begin{tabular}{|c|c|c|}
\hline & Score & Category \\
\hline A & $90-100$ & Excellent \\
\hline B & $80-90$ & Best \\
\hline C & $70-80$ & Good \\
\hline D & $60-70$ & Enough \\
\hline E & $<60$ & Less than \\
\hline
\end{tabular}

\section{Technique of Data Collection}

Techniques used by the researcher in collecting data are interview, observation and test. Each technique of data collection is described below:

1. Interview

Lecturer makes a list of question which It'll be questioned. It's about the information that related with the clustering technique. Then lecturer interviews to the students after cycle. The aim of the interview is to know more about the learning writing.

2. Observation

Lecturer record the data when implementation mind mapping technique in students' writing skill. Lecturer observes teaching material, technique and what kind of media that use in teaching writing. Then write down learning activities in observing.

3. Test

Lecturer give independent essay test to the students. This test was given to students in the end of each cycle. This function is to determine mind mapping technique can improve students' writing skill in cycle I and cycle II.

\section{Technique of Data Analysis}

1. Data Reduction

Data will make resume and also choose the important and discard unnecessary. Lecturer will selection of relevant data. 


\section{Data Description}

Lecturer studies the data in each of cycle, the analyzes the weakness and the problems during activity and determines what solution to solve the problem in cycle I and cycle II. Data description are shown descriptively with symbol, chart or picture.

3. Data Verification

Lecturer makes conclusion and interpret data based on the result of description data.

\section{Validity of Data}

In this research, lecturer used face validity, according to S. Arikunto (2012:128) the observers together check, make score and decide each other the validity of instrument in process of collaboration. Then lecturer conducted triangulation, according to Burns (1999:163) triangulation is one of the most commonly used and best known ways of checking for validity. The aim of triangulation technique is to gather multiple perspective on the situation being studied. After that lecturer conducted critical reflection, it's about planning for improving students' writing skill by cycle

\section{Criteria of the Successful Research}

It was able to called successful in Classroom Action Research (CAR), if $100 \%$ students could pass the assessment. The students was gotten score same or above the minimum mastery criteria in writing English 75.

\section{Steps of the Research}

This research consists of two cycle. Each of cycle are four steps. Those steps are planning, acting, observing and reflecting.

\section{a. Cycle I}

In this cycle, lecturer describe process in teaching learning writing English:

\section{Planning}

Lecturer make design material which suitable with the syllabus writing. Basic Competence in cycle I is students have writing skill with the content, language use, vocabulary and also mechanics.

\section{Acting}

Lecturer make steps are greeting, introduce her/him self to the students, asking about the activity was doing in the last night and also checking students' attendance. Lecturer explain the material which has relation with the writing skill. Beside that lecturer introducing what's clustering technique. Written which students' write are kind of text such as descriptive text, report text, procedure text. Each of students have to make written through clustering technique.

\section{Observing}

Lecturer conducted observe when processing learning writing. Lecturer have seen the activity when students was writing. In cycle I, students still didn't get the idea or theme which it will be written through clustering technique. Students still difficult in making concept cluster. Also Students have many question to the lecturer from what should they do first in making cluster.

\section{Reflecting}

Reflecting in this cycle is the last steps as long as observation and learning in classroom. Lecturer write what are the difficult when learning writing in cycle I also lecturer decided score or grade based on criteria score writing skill. Lecturer gives motivation to the students in writing 
process and also find how is the way solve the problem on students' writing skill. Students feel enthusiasm for finishing written in English.

In cycle I, students passes learning writing $32 \%$ and students was failed $68 \%$ in writing skill

\section{b. Cycle 2}

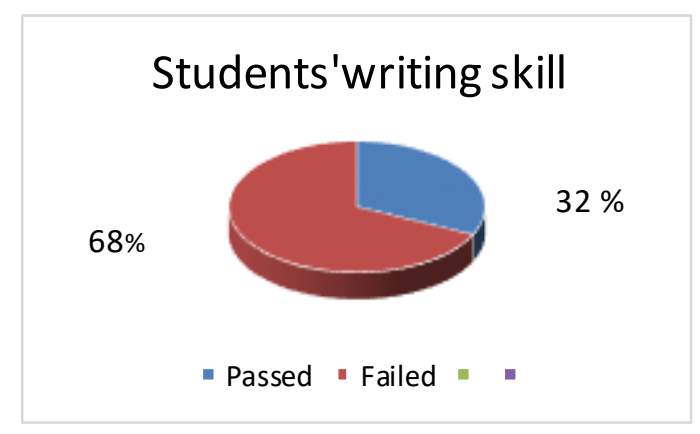

From the result of the cycle I, lecturer continue to the next cycle. In cycle II, it can be describe :

\section{Planning}

Lecturer make planning what are the objective goal in teaching and learning writing. Lecturer see the syllabus and then determine what are the basic competency which it have been done. Lecturer explain definition clustering technique. After that students asked to make mind mapping in one of paper. Students ask by the lecturer to bring coloring pen, coloring pencil or crayon. It uses to write a shape, picture or something else that support in clustering technique.

\section{Planning}

Lecturer greeting to the students then ask students to pray before they begin the lesson. Lecturer check attendance students then asking about the material of the lesson which lecturer given to the students in the last meeting. Lecturer divided students' group. It consists of three - four person. Students was given random by lecturer in theme writing. There are group who write describing place, write students' ambition or dream in the future several years later, write about member of family and also problem which gotten in everyday such as traffic jam transportation. Every students make concept with picture and also kind of coloring pens in order that It can be seen excited. They written an idea that mapping in a paper then they arrange sentences to text.

\section{Observing}

Students have been determined theme which they was taken then put it in writing. Students enthusiasm when they make an writing, lecturer walk around while seeing students' work. When students didn't understand, lecturer explain the material of the lesson. Lecturer write down the data when students' learning process.

\section{Reflecting}

It was the last steps in this cycle. In this cycle, students give positive response as long as learning process. In writing process, students pay attention in vocabulary, grammar and also mechanics writing in order that they didn't feel difficult. In this cycle students passed $88 \%$ and students was failed $12 \%$. It can be seen in the diagram below : 


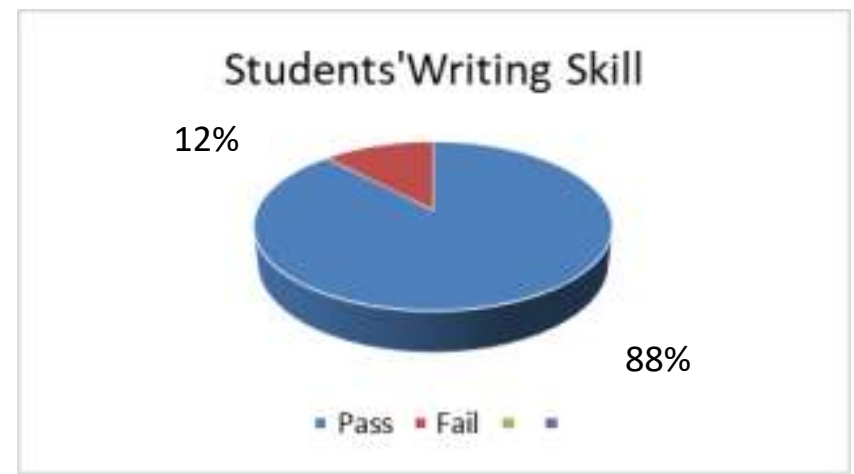

In learning writing process, lecturer use Clustering technique in transferring lesson material. Clustering technique is one of the technique which diagram a concept or idea in one a paper and also It was given coloring pens. After that students write in English from the idea which It develops through clustering. Students make creation in clustering concept before they write in English. Using picture, shapes and kind of colors. They become creative, imaginative in visual

\section{CONCLUSION}

Based on the result of the research improving students' writing skill through Clustering technique on STKIP Kusuma Negara, Jakarta. Clustering technique can improve writing' skills significant. In cycle I, it can be shown that $32 \%$ Students passed writing skill and $68 \%$ students was failed in writing skills. From observed, in cycle I students still difficult determined theme in writing, students difficult find supporting details, they have been never yet use clustering to develop writing. When students write a text, students focus with the concept in order that they didn't write the outside of the concept. Moreover result of the writing appropriate with the objective teaching. In cycle II, $88 \%$ students was passed writing skill and $12 \%$ students was failed writing skills. After they got knowledge about clustering technique, they can improve what they know in writing skills. They can increase their ability in writing using English language. In writing, students needs structure and grammar mastery, vocabulary mastery and also guidelines in writing. Those can support students in writing skill. Students are able to write in English and they can get a good written.

\section{REFERENCES}

Arikunto, Suharsimi. (2012). Dasar-dasar Evaluasi Pendidikan. Jakarta: Bumi Aksara

Burns, Anne.(1999). Collaborative Action Research for English Language Teachers. New York: Cambridge University press, p.163

Harmer, Jeremy. (2007). The Practice of English Language Teaching Fourth edition. London: Longman Pearson Education

Heaton, J. B. (1998). Writing English Language Test. Edinburg Gate: London and New York. 
Langan, John. (2008). College Writing Skill with Reading. : English Skill. Seventh Edition. New York: Mc Graw Hill Higher Education

Megawati, M. (2017). THE IMPROVING STUDENTS'READING COMPREHENSION THROUGH GRAMMAR TRANSLATION METHOD. ENGLISH EDUCATION: JOURNAL OF ENGLISH TEACHING AND RESEARCH, 2(2), 95-108. doi:10.29407/jetar.v2i2.833 Date accessed: 02 apr. 2019 http://ojs.unpkediri.ac.id/index.php/inggris/article/view/833

Pharr, Donald and Santi V, Buscemi. (2005). Writing Today. New York: McGraw Hill

Rabadia, Edi Sut Ode. (2018). Improving Students'Writing skill through clustering Techniques at The Eight Grade of SMP Negeri Karang Jaya. Available at https://www.researchgate.net/publication/327403099

Riswanto and Pebri Pandika Utama. (2012). The Use of Mind Mapping Strategy in the Teaching of Writing at SMAN 3 Bengkulu, Indonesia. International Journal of Humanities and Social science. Vol.2 No.21: November 2012

Wati, Dian Reftya. (2018). Improving the students'descriptive text writing ability through the implementation of clustering technique at the tenth grade of MAN 1 Metro. English Education: Jurnal Tadris Bahasa Inggris. P-ISSn 2086-6003, Vol 11(1),2018,129-143. Taken from November $28^{\text {th }} 2019$ https://ejurnal.radenintan.ac.id/index.php/ENGEDU

Widyawati, Wiwik. (2018). The Use of Clustering Technique for Improving Writing Description Text Of The Third Semester Students Of Unindra. Jurnal Kredo Vol. 1 No.2 April 2018. ISSN 2599-316X. p136

Wiguna, I.P.M.W, D.K Tantra, L.D.S Andnyani. (2019). Improving The Seventh Grade Students'Writing Competency Through Clustering Technique At SMPN 6 Singaraja Academic Year 2014/2015. Jurnal Pendidikan Bahasa Inggris Undiksha, Vol. 7 No. 01, 2019 ISSN: 2614-1892 